\title{
Ecotypic Variation in Tripsacum dactyloides Evaluated in Texas
}

\author{
T.G. SCHLIESING AND B.E. DAHL
}

\section{Abstract}

Eastern gamagrass collections (26) from throughout Texas, except the Trans-Pecos, and from southern Oklahoma (3) were evaluated in a common garden at Uvalde, Texas, to select an ecotype suitable for planting in central and south Texas. Four potential ecotypes existed among the collections with a fifth existing in collections from extreme southeast Texas. The characters of this latter type overlapped those of collections from north Texas making it less distinet from the others. Collections (Type C) from central and west $T$ exas were superior to all others in forage production, crude protein, and chlorophyll content. Collections from near Baird and Bracketville were outstanding and further field evaluation is warranted.

Eastern gamagrass (Tripsacum dactyloides (L.) L.) is one of the highest producing native grasses in Texas and it is among the most palatable.

According to Polk and Adcock (1964), early settlers in Texas found this grass covering thousands of acres in almost pure stands. They believe it was important in one-third of Texas and it was found scattered throughout Texas. Because of this high palatability, it primarily remains in only a few isolated areas in swales, streambanks, and moist places (Hitchcock 1951) in the drier portions of Texas that are seldom frequented by domestic livestock. In rare instances it is still managed for hay and grazing on farms and ranches in central Texas and along the Gulf Coast. Because of its high forage potential, we were interested in finding planting material from among eastern gamagrass collections from Texas and southern Oklahoma with characteristics deemed desirable as planting stock for central and south Texas. Thus, the major objective of this study was to evaluate eastern gamagrass collections in a common garden at Uvalde, Texas, to search for high producing ecotypes with desirable nutritional characteristics. This paper presents the first phase or the selection of potentially useful ecotypes from the eastern gamagrass collections available to us. Cutler and Anderson (1941) reported sufficient morphological differences in the Trans-Pecos area populations in west Texas to merit variety rank, Tripsacum dactyloides var. occidentale, although it is apparently not so recognized now (Gould 1975). We made no collections from this area.

Eastern gamagrass occurs in at least 26 states in the eastern half of the United States, south through Mexico to Central America, and the West Indies (Cutler and Anderson 1941). Gould (1975) shows eastern gamagrass in every major vegetational area in Texas.

Galinat et al. (1964) suggests considerable age for the genus Tripsacum due to the "differentiation of Tripsacum into nine diverse species distributed throughout much of the New World." Wilkes (1972) theorized that the "center of variation for Tripsacum is the western escarpment of central Mexico." According to him "seven of the nine recognized species are native to Mexico and Guatemala, an eighth, Tripsacum floridanum, is native to Florida and the Gulf Coast of Texas and the ninth, Tripsacum australe

\footnotetext{
Authors are instructor in agriculture, Southwest Texas Junior College, Uvalde, and professor, range and wildlife management, Texas Tech University, Lubbock.
}

(and possibly other undescribed species) is native to South America." Randolph (1970) studied the variation among Tripsacum populations of Mexico and Guatemala and concluded that the evolution of new taxa is "continuing as a contemporary phenomenon wherever sympatric associations of cross-compatible and morphologically different diploid and tetraploid taxa exist in adjoining habitats." Tantravahi (1971) used 8 morphological characters and discriminant function analysis to separate 4 populations of the Tripsacum lanceolatum complex. We also used morphological plus some chemical characteristics to separate our collections into potential ecotypes.

\section{Materials and Methods}

Easten gamagrass collections were divided into ramets and randomly placed in a transplant plot at Uvalde, Texas, during the spring of 1971. The transplant garden is uniformly level and the soil is a Montell Clay. The rainfall averages approximately $600 \mathrm{~mm}$ with about $80 \%$ occurring during April through October.

Clonal material was obtained from 2 sources. The first was through the United States Department of Agriculture, Soil Conservation Service, James E. "Bud" Smith Plant Materials Center located at Knox City, Texas. Soil Conservation Service collections

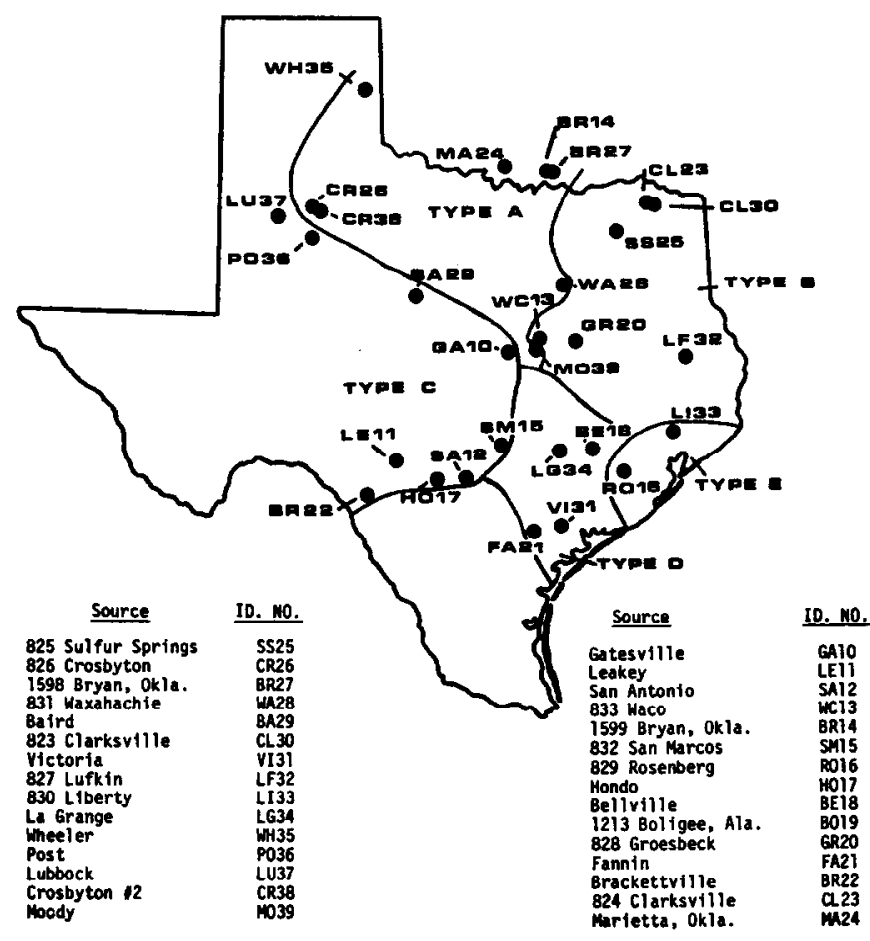

Fig. 1. Map showing location of eastem gamagrass collections and the ecotype to which each collection was placed by discriminant function analysis. 
originated from 14 service collections from Texas and Oklahoma. The second source was from private collections made during December, 1970. These private collections were from 16 populations in Texas. (The location of all collections with the ID number are plotted on the Texas Collection Site and Type Map (Fig. 1)). The collection sources on the map legend with numerical prefixes retain the original Soil Conservation Service ID number (Fig. 1).

The common garden included 5 replications each from the 30 collections. Each plant was randomly placed in the transplant garden. The transplant garden was established in spring, 1971 on a small irrigated field adjacent to the Southwest Texas Junior College campus in Uvalde, Texas.

Information collected was grouped into environmental variables and plant variables. Environmental variables included latitude and longitude to the nearest degree; elevation to the nearest $15 \mathrm{M}$; mean annual precipitation in $\mathrm{mm}$; January mean minimum temperature; July mean maximum temperature; length of growing season in days; soil texture expressed as percent clay content; and topographic position with reference to range site, as used by Dahl (1966). The topographic position index ranged from a value of $I$ for the driest site to a 5 for the wettest site.

Plant variables included number of flowering culms; number of lateral flowering branches per culm; color of stigma; leaf width $(\mathrm{mm})$; leaf length $(\mathrm{cm})$; first clipping forage production $(\mathrm{g})$; second clipping forage production (g); crude protein (\%); carotene ( $\mathrm{mg} / \mathrm{kg}$ ); chlorophyll $a$ and $b(\mathrm{mg} / \mathrm{g})$; and color of leaf (Munsell Color Chart).

The 14 plant variables were measured during the growing season of 1972. The number of flowering culms were counted at the first of 2 clippings on July 1,1972 . Plants were clipped at a $15-\mathrm{cm}$ height to insure maintenance of a healthy plant. The contour of the rootcrown was followed so that all culms were clipped to a $15-\mathrm{cm}$ level.

Separation of vegetative and flowering culms was facilitated by the growth habit of eastern gamagrass. Eastern gamagrass is a vigorous bunchgrass producing multiple tillers which expands plant diameter under favorable conditions (Dewald and Louthan 1979). Most tillers were vegetative at the time of clipping. Vegetative and flowering culms were easily separated when clipped. The second clipping was made on December 31, 1972. The first killing frost occurred at the transplant plot on December 16, 1972, when the temperature dropped to $-8.9^{\circ} \mathrm{C}$. Prior to this the collections from north Texas and southern Oklahoma showed signs of dormancy although the lower half of the plant remained green. Collections from the Texas coastal area remained completely green although they apparently were not actively growing.

Leaf blade width was measured at the widest point on blades taken at random from the outer perimeter of the plant. Five measurements per plant were averaged to determine blade width and length. Crude protein was determined by the Kjeldahl method. All chemical analyses were determined on plant tissue collected and dried on July 1, 1972. Carotene was determined as outlined by Goodwin (1955). Chlorophyll $a$ and $b$ were analyzed according to the method described by Arnon (1949).

Discriminant Function Analysis Program BMD-07M, edited by Dixon (1973), was used to allocate collections to "type" groups. Discriminant analysis was first applied to plant variables and subsequently applied to environmental variables.

\section{Results and Discussion}

Using the discriminant function approach to separate potential ecotypes, 3 groupings were required to discriminate the type groups using the 14 plant variables. The first grouping was based subjectively on initial data collected during 1971 , the year of establishment. This grouping indicated 4 potential ecotypes. Field measurements used to place the collections into the 4 type groups included: leaf width, color of leaves, leaf length, number of flowering culms, relative size of plants, and growth habit (upright to decumbent).

The second grouping into 4 potential ecotypes was obtained rom discriminant analysis, but using the second year (1972) field data. All values measured were included. Because the plants were well established by the second year, it was believed these data were more indicative of true differences among the collections. When compared with the 1972 data, several collections displayed a typical morphological expression during 1971. Because of this difference in response between years, data collected during the year of establishment should be less satisfactory unless used strictly for establishment studies.

After the second iteration, it was clear that 2 collections, R016 and LI33 did not fit well into any of the selected types. Therefore, a third iteration resulted in the retyping of the 2 collections into a fifth type. The accuracy of the first subjective grouping when compared with that finally delineated by discriminant analysis, was $86 \%$ correct.

Confidence intervals for canonical analysis of 14 plant variables are graphed in Figure 2. It is assumed that if the confidence limits do not overlap, potential ecotypes exist, at least mathematically. Since both conditions exist, it must be assumed that an ecocline exists among members of Types $B$ and $E$. All other types appeared discrete. The types are on the Texas Collection Site and Type Map (Fig. 1).

The final groupings resulting from analysis of plant variables were checked using only the environmental variables. Based on this final discriminant analysis, all collections fit into the same type groups as those set by analysis of plant variables.

\section{Morphlogical Differences}

The leaf color was bluish-green for all collections from Type A, and varied only slightly from a true green for the rest of the state. Leaf width extremes were from $13 \mathrm{~mm}$ for the Wheeler, WH35 collection to $24 \mathrm{~mm}$ for the Victoria, V131 collection. Type A collections displayed narrow leaves and Type $D$ the widest leaves. Leaf length extremes ranged from $52 \mathrm{~cm}$ for the Lufkin, LF32 collection to $107 \mathrm{~cm}$ for the VI31, Victoria collection. Type D collections had the longest leaves. Stigma color was consistently green for the Type $C$ collections and consistently maroon for the Type D collections. A number of collections in the other types had an intermediate stigma color. Number of flowering culms per plant was erratic even within collection replicates. However, number of lateral flowering branches per culm was more consistent. Total forage production, exclusive of flowering culms, ranged from $147 \mathrm{~g}$ per plant for Sulfur Springs, SS25, to $1,738 \mathrm{~g}$ per plant for BA29, Baird. Crude protein ranged from 9.3\% for Sulfur Springs, SS25, to $15.7 \%$ for the GA10, Gatesville collection. Baird, BA29 collection scored $14.5 \%$ crude protein for the second high average and highest for forage production average. SS25, Sulfur Springs had the low average for both. The carotene content varied within

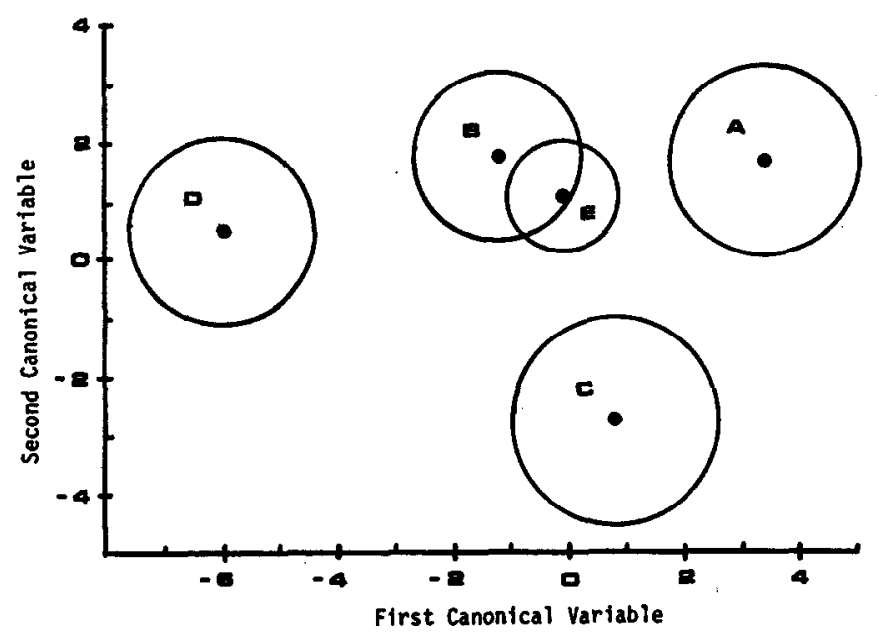

Fig. 2. Confidence intervals for canonical analysis of 14 plant variabiles of eastern gamagrass ecotypes collected in Texas and southern Oklahoma. 
Table 1. Yleld, crude proteln, carotene, and chlorophyll a and b for eastern gamafrass ecotypes.

\begin{tabular}{|c|c|c|c|c|c|}
\hline Collection number & $\begin{array}{l}\text { Crude protein } \\
\text { (\%) }\end{array}$ & $\begin{array}{l}\text { Yield } \\
\text { (grams/plant) }\end{array}$ & $\begin{array}{l}\text { Carotene } \\
(\mathrm{mg} / \mathrm{kg})\end{array}$ & $\begin{array}{l}\text { Chlor. a } \\
\text { (mg/g) }\end{array}$ & $\begin{array}{l}\text { Chlor. b } \\
(\mathrm{mg} / \mathrm{g})\end{array}$ \\
\hline $\begin{array}{l}\text { BR27 } \\
\text { BR14 } \\
\text { WA28 } \\
\text { CR26 } \\
\text { MA24 } \\
\text { WH35 } \\
\text { MO39 }\end{array}$ & $\begin{array}{r}11.0 \\
9.7 \\
10.8 \\
11.2 \\
11.6 \\
11.1 \\
10.9 \\
\end{array}$ & $\begin{array}{l}507 \\
457 \\
492 \\
625 \\
282 \\
369 \\
817 \\
\end{array}$ & $\begin{array}{l}A \\
11.8 \\
10.0 \\
13.2 \\
13.2 \\
12.6 \\
14.0 \\
11.3 \\
\end{array}$ & $\begin{array}{l}1.57 \\
1.22 \\
1.79 \\
1.55 \\
1.81 \\
1.75 \\
1.72 \\
\end{array}$ & $\begin{array}{l}0.55 \\
0.40 \\
0.63 \\
0.57 \\
0.69 \\
0.64 \\
0.63\end{array}$ \\
\hline $\bar{x}$ & 11.0 & 490 & 12.4 & 1.65 & 0.60 \\
\hline $\begin{array}{l}\text { LF32 } \\
\text { SS25 } \\
\text { GR20 } \\
\text { B019 } \\
\text { WC13 } \\
\text { CL23 }\end{array}$ & $\begin{array}{r}10.6 \\
9.3 \\
10.2 \\
9.9 \\
10.5 \\
13.6 \\
\end{array}$ & $\begin{array}{l}109 \\
187 \\
328 \\
248 \\
590 \\
480 \\
\end{array}$ & $\begin{array}{l}\text { B } \\
13.0 \\
11.8 \\
15.6 \\
12.2 \\
16.0 \\
10.0 \\
\end{array}$ & $\begin{array}{l}1.60 \\
1.48 \\
1.36 \\
1.35 \\
1.62 \\
1.63 \\
\end{array}$ & $\begin{array}{l}0.57 \\
0.49 \\
0.43 \\
0.47 \\
0.52 \\
0.59 \\
\end{array}$ \\
\hline $\bar{x}$ & 10.2 & 324 & 13.6 & 1.45 & 0.49 \\
\hline $\begin{array}{c}\text { LU37 } \\
\text { PO36 } \\
\text { BA29 } \\
\text { GA10 } \\
\text { SM15 } \\
\text { SA12 } \\
\text { HO17 } \\
\text { LE11 } \\
\text { BR22 }\end{array}$ & $\begin{array}{l}13.4 \\
12.1 \\
14.5 \\
15.7 \\
12.1 \\
10.9 \\
13.9 \\
11.2 \\
14.0\end{array}$ & $\begin{array}{r}1190 \\
1140 \\
1738 \\
630 \\
1266 \\
1584 \\
463 \\
1227 \\
1441\end{array}$ & $\begin{array}{l}\mathrm{C} \\
12.0 \\
14.4 \\
15.4 \\
11.8 \\
13.4 \\
11.8 \\
14.0 \\
12.4 \\
15.6\end{array}$ & $\begin{array}{l}2.06 \\
1.92 \\
1.71 \\
1.47 \\
2.08 \\
1.93 \\
1.69 \\
1.84 \\
1.76 \\
\end{array}$ & $\begin{array}{l}0.78 \\
0.69 \\
0.61 \\
0.50 \\
0.77 \\
0.71 \\
0.57 \\
0.70 \\
0.63\end{array}$ \\
\hline $\bar{x}$ & 13.1 & 1238 & 13.3 & 1.84 & 0.67 \\
\hline $\begin{array}{l}\text { V131 } \\
\text { FA21 } \\
\text { LG34 } \\
\text { BE18 }\end{array}$ & $\begin{array}{l}10.8 \\
13.6 \\
13.7 \\
10.7 \\
\end{array}$ & $\begin{array}{r}912 \\
1532 \\
1595 \\
543 \\
\end{array}$ & $\begin{array}{l}\mathrm{D} \\
16.0 \\
13.8 \\
19.0 \\
18.7 \\
\end{array}$ & $\begin{array}{l}1.92 \\
1.54 \\
1.80 \\
1.85 \\
\end{array}$ & $\begin{array}{l}0.69 \\
0.57 \\
0.63 \\
0.66 \\
\end{array}$ \\
\hline $\bar{x}$ & 12.4 & 1192 & 16.7 & 1.81 & 0.63 \\
\hline $\begin{array}{l}\text { RO16 } \\
\text { LI33 }\end{array}$ & $\begin{array}{l}11.2 \\
10.0 \\
\end{array}$ & $\begin{array}{l}993 \\
995 \\
\end{array}$ & $\begin{array}{l}\mathrm{E} \\
15.0 \\
13.0 \\
\end{array}$ & $\begin{array}{l}1.82 \\
1.68 \\
\end{array}$ & $\begin{array}{l}0.65 \\
0.59 \\
\end{array}$ \\
\hline $\bar{x}$ & 10.6 & 993 & 14.0 & 1.75 & 0.62 \\
\hline
\end{tabular}

groups; the Type D collections had the highest averages and the collections from Type $A$ had the lowest averages. Chlorophyll a and $b$ were highest in Type $C$ collections and lowest in collections from the Type $B$ area.

This study shows that differences potentially exist among eastern gamagrass populations in Texas and Oklahoma. It would be possible to allocate newly discovered populations into the established type groups on the basis of collection site environmental data only. Because Types $A, B, C$, or $D$ all potentially occur in the Waco area, use of a morphological key is necessary for that area. The needed refinement of type boundaries in the Waco area could probably be accomplished with more intense sampling.

\section{Agricultural Types}

A major reason for conducting this study was to isolate potentially useful selections for improved pastures. Desirable attributes for a pasture selection should include relatively high forage production, protein, and carotene (Table 1). This study identifies selections most ideally suited for growth on calcareous soils of Types $C$ and $D$ areas. Without reciprocal transplants to other type areas in Texas, it is difficult to say how well these results would apply to these areas. Nevertheless, the variability shown by ecotypes in productivity, protein content, and carotene content demonstrates the desirability for testing selections of eastern gamagrass before propagating it as a pasture grass in any area.
For the Uvalde area, Type C collections are superior to all other types for both forage production and protein content. The carotene content for Type Collections was higher than all types except Type D. Within the collections from Type C, BA29, Baird, and BR22, Brackettville appear outstanding and worthy of further evaluation. They were the highest forage producers in the entire study and with the exception of GA10, Gatesville, had the highest protein content. Field evaluation of these collections is recomended.

\section{Literature Cited}

Arnon, D. 1949. Copper enzymes in isolated chloroplasts. Plant Physiol. 24:1-15.

Cutler, H.C., and E. Anderson. 1941. Preliminary survey of the genus Tripsacum. Ann. Missouri Bot. Garden. 28:249-269.

Dahl, B.E. 1966. Environmental factors related to medusahead distribution. Unpub. Diss., Univ. Idaho.

Dewald, C.L., and V.H. Louthan. 1979. Sequential development of shoot system components in Eastern gamagrass. J. Range Manage. 32:147-151.

Dixon, W.J. (ed.). 1973. BMD Biomedical Computer Programs. Health Science Computing Facility, Univ. California, Los Angeles.

Galinat, W.C., R.S.K. Chazant, and F.D. Hager. 1964. Tripsacum as a possible amphidiploid of wild maize and Manisuris. Bot. Mus. Leafl. 20:289-316.

Goodwin, T.W. 1955. Carotenoids. In: K. Peach and M. V. Tracey, Methods of Plant Analysis 3:272-311. 
Gould, F.W. 1975. The grasses of Texas. Texas plants, a checklist and ecological summary. Texas A\&M Univ. Press, College Station.

Hitchcock, A.S. 1951. Manual of the grasses of the United States. U.S. Govt. Printing Office, Washington, D.C. Revised by A. Chase.

Polk, D.B., and W.L. Adcock. 1964. Eastern gamagrass. The Cattleman 50:82-84.
Randolph, L.F. 1970. Variation among Tripsacum populations of Mexico and Guatemala. Brittonia 22:305-337.

Tantravahi, R.V. 1971. Multiple character analysis and chromosome studies in the Tripsacum lanceolatum complex. Evolution. 25:38-50.

Wilkes, G.H. 1972. Maize and its wild relatives. Sci. 177:1071-1077. 